\title{
The shape of the HIV/AIDS epidemic in Puerto Rico
}

\author{
Maria A. Gomez, ${ }^{1}$ Diana M. Fernandez, ${ }^{1}$ Jose F. Otero, ${ }^{1}$ \\ Sandra Miranda, ${ }^{2}$ and Robert Hunter ${ }^{1}$
}

\begin{abstract}
This study presents information on AIDS patients in Puerto Rico, including their general sociodemographic profile, some risk-related parameters, characteristics of vulnerable groups, and elements of the clinical spectrum of the disease. Data were analyzed from the Puerto Rico AIDS Surveillance Program and available studies about the HIV/AIDS epidemic in Puerto Rico. A total of 23089 AIDS cases was reported to the Puerto Rico AIDS Surveillance Program from January 1981 through February 1999. The HIV/AIDS epidemic has affected mostly males and females between the ages of 30 and 49 , though cases have also been reported for other age groups. The cumulative proportion of persons with AIDS who are women has increased tremendously, from $11.4 \%$ for the 1981-1986 period to $21.6 \%$ for the entire 1981-1999 period. In Puerto Rico the category of injecting drug users (IDUs) accounts for the majority of the AIDS cases (52\%), followed by heterosexual contact (22\%), and men who have sex with men (17\%). The three main diagnoses for AIDS on the island are wasting syndrome (30.7\%); esophageal, bronchial, and lung candidiasis (29.4\%); and Pneumocystis carinii pneumonia (26.8\%). According to 1994 vital statistics for Puerto Rico, AIDS was the fourth-leading cause of death. The overall reported AIDS mortality rate was 42.0 per 100000 persons, with the rate for males, 67.8, much higher than it was for females, 17.4. AIDS is the first cause of death among persons between 30 and 39 years old. Intense efforts are needed to better understand the epidemic in Puerto Rico and its biology, social and family impacts, and financial costs.
\end{abstract}

In 1992 the noted researcher Jonathan Mann and colleagues of his said that the global HIV/AIDS epidemic was still volatile, dynamic, and unstable; that its major impacts were yet to come; and that its shape and future depended on individual and collective

1 Universidad Central del Caribe, Internal Medicine Department, Retrovirus Research Center, Bayamón, Puerto Rico. Send correspondence to: Maria A. Gomez, Retrovirus Research Center, Internal Medicine Department, Universidad Central del Caribe, Bayamón, Puerto Rico 00960-6032. Telephone: (787) 787-8710; fax: (787) 787-8733; e-mail: mgomez@caribe.net

2 Commonwealth of Puerto Rico, Health Department, Puerto Rico AIDS Surveillance Program, San Juan, Puerto Rico. human behavior (1). Since then, considerable progress has been made in understanding the HIV/AIDS epidemic, the determinants and distribution of that epidemic in different populations, the clinical spectrum of the epidemic, and its synergistic effects with other epidemics. Nevertheless, there is much that needs to be better understood.

Estimates of the magnitude of the epidemic are generally based on reported AIDS cases, which are believed to be underreported around the world. In 1992, according to the World Health Organization (WHO), 12.9 million people around the world were infected with the HIV virus. According to a WHO report from December 1998, over the ensuing six years, the number of people infected rose to 33.4 million, an increase of $159 \%$ (2). The Joint United Nations Programme on HIV/ AIDS (UNAIDS) and WHO estimated that 16000 persons per day became HIV-infected during 1998 (3). Up through December 1998, $41.6 \%$ of all AIDS cases had died, with 2.5 million deaths in 1998 alone.

Even as different aspects of the epidemic are better defined and there is an immense global effort against HIV and AIDS, the HIV virus continues to spread. This is particularly true in the 
developing world, where more than 95\% of all HIV-infected people live. UNAIDS and WHO have reported that in most of Latin America and the Caribbean the pattern of HIV spread is much the same as in industrialized countries, with the main modes of transmission being men having unprotected sex with other men, and injecting drug users (IDUs) sharing needles (3).

In Puerto Rico a total of 23089 AIDS cases was reported to the Puerto Rico AIDS Surveillance Program from January 1981 through February 1999 (4). According to data from the United States Centers for Disease Control and Prevention (CDC), Puerto Rico had the fourth-highest incidence of AIDS cases among the states and territories of the United States of America during the period of July 1997 through June 1998 (5). The rate for Puerto Rico, 52.8 per 100000 inhabitants, was only exceeded by the incidence rates in the District of Columbia (178.3), the state of New York (62.5), and the U.S. Virgin Islands (55.9).

Similar results come from looking at data for the major metropolitan areas of the United States with the highest incidence of AIDS cases over a period of several years, including San Juan, Puerto Rico's capital and largest city (Table 1). Of the seven metropolitan areas shown in Table 1, San Juan was the only one that showed an increase for the 12-month period ending with June 1997. And while all seven of the metropolitan areas showed decreases in incidence rates for the 12 months ending in June 1998, San Juan had the smallest of those declines (5).

The objective of the present study is to present information on AIDS patients in Puerto Rico, including a general sociodemographic profile, riskrelated parameters, and characteristics of groups that are particularly vulnerable. The study also covers elements of the clinical spectrum of the disease.

For our study, we analyzed data from the Puerto Rico AIDS Surveillance Program and available studies about the HIV/AIDS epidemic in Puerto Rico. According to data from the Puerto Rico AIDS Surveillance Program (6), the largest number of AIDS

TABLE 1. Metropolitan areas of the United States of America with the highest incidence of AIDS cases (per 100000 population) in the preceding 12 months

\begin{tabular}{lccr}
\hline \multicolumn{1}{c}{ Metropolitan area } & June 1996 & June 1997 & June 1998 \\
\hline New York, New York & 131.0 & 117.2 & 101.2 \\
Miami, Florida & 115.5 & 86.6 & 76.4 \\
Jersey City, New Jersey & 114.5 & 109.8 & 72.2 \\
San Francisco, California & 108.5 & 83.1 & 69.7 \\
Fort Lauderdale, Florida & 86.4 & 78.4 & 56.2 \\
West Palm Beach, Florida & 85.3 & 73.0 & 53.9 \\
San Juan, Puerto Rico & 66.3 & 70.2 & 63.3 \\
\hline
\end{tabular}

Source: United States, Centers for Disease Control and Prevention. HIV/AIDS Surveillance Report, June 1998.

TABLE 2. AIDS exposure categories in Puerto Rico among adults and adolescents, January 1981-February 1999a

\begin{tabular}{|c|c|c|c|c|c|c|}
\hline \multirow[b]{2}{*}{ Exposure category } & \multicolumn{2}{|c|}{ Males } & \multicolumn{2}{|c|}{ Females } & \multicolumn{2}{|c|}{ Total } \\
\hline & No. & $\%$ & No. & $\%$ & No. & $\%$ \\
\hline Injecting drug use & 9791 & 55 & 1908 & 39 & 11699 & 52 \\
\hline Men who have sex with men & 3797 & 21 & 0 & 0 & 3797 & 17 \\
\hline Heterosexual contact & 2130 & 12 & 2901 & 58 & 5031 & 22 \\
\hline $\begin{array}{l}\text { Men who have sex with men and } \\
\text { inject drugs }\end{array}$ & 1690 & 10 & 0 & 0 & 1690 & 7 \\
\hline $\begin{array}{l}\text { Receipt of blood transfusion, } \\
\text { blood components, or tissue }\end{array}$ & 101 & 1 & 122 & 2 & 223 & 1 \\
\hline Risk not reported/Other & 182 & 1 & 57 & 1 & 239 & 1 \\
\hline Total no. of cases & \multicolumn{2}{|c|}{17691} & \multicolumn{2}{|c|}{4988} & \multicolumn{2}{|c|}{22679} \\
\hline
\end{tabular}

Source: Puerto Rico AIDS Surveillance Program.

a This table does not include 410 pediatric cases, for whom exposure categories were different.

cases on the island from January 1981 through February 1999 were in the health regions of San Juan (5 791 cases), Ponce (3 969), and Bayamón (3 841).

\section{SOCIODEMOGRAPHIC SPECTRUM}

Information from the Puerto Rico AIDS Surveillance Program showed that between January 1981 and February $1999,45 \%$ of all the reported AIDS cases had occurred among those 30-39 years old, 24\% among those 40-49 years old, 18\% among those 20-29 years old, and $11 \%$ among those 50 and older (4). Among adolescents in Puerto Rico, from January 1981 through September 1996, for every adolescent fe- male with AIDS, there were two adolescent males with the syndrome. That male-female ratio increased with age. For example, for those aged 30 to 39 years, the ratio was 3.3:1 (7).

\section{BEHAVIORAL SPECTRUM}

There are differences in HIV exposure categories between the continental United States and the island of Puerto Rico. Information from the Puerto Rico AIDS Surveillance Program (4) shows that in Puerto Rico the category of injecting drug users (IDUs) accounts for a slight majority of the cases (52\%), followed by heterosexual contact $(22 \%)$ and men who have sex with men (17\%) (Table 2). In contrast, 
in the continental United States the main exposure category among adults and adolescents continues to be the men having sex with men ( $48 \%$ ), followed by IDUs $(26 \%)$ and by heterosexual contact $(10 \%)(5)$. Thus the risk profile of HIV/AIDS patients in Puerto Rico is similar to the one for Western Europe, North Africa, and the Middle East (2).

Differences between gender and exposure categories are also found between Puerto Rico and the mainland United States. In Puerto Rico the most frequent exposure category among males is injecting drug use (55\%), followed by men having sex with men $(21 \%)$. In contrast, in the continental United States the most frequent exposure category among males is men who have sex with men $(57 \%)$, followed by IDU (22\%). Among females, the first exposure category in Puerto Rico is heterosexual contact ( $58 \%$ ), followed by IDU $(38 \%)$. In the mainland United States the rankings are reversed, with $43 \%$ for IDU and 39\% for heterosexual contact. In Puerto Rico, one study of HIV patients showed that a large proportion of them combined risk practices, in particular the use of injecting drugs and heterosexual activity with different partners (8).

\section{Injecting drug use}

Recent literature has shown the growing significance of injecting drug use in the HIV/AIDS epidemic in Puerto Rico, as well as among Puerto Ricans residing in the continental United States (9-13). Preliminary data from the Human Retrovirus Registry of the Universidad Central del Caribe in Bayamón, Puerto Rico, has demonstrated that injecting drug users are exposed to many more risk situations than are other risk groups involved in the epidemic (14). According to data from that registry, in Puerto Rico IDUs have a mean age of 35 years, and most are males. The IDUs have a spectrum of social vulnerabilities, including unemployment, a very low educational level, multiple heterosexual contacts, and work as prostitutes.

TABLE 3. Clinical spectrum of AIDS in Puerto Rico, January 1981 through February 1999

\begin{tabular}{lcc}
\hline \multicolumn{1}{c}{ Most frequent disease categories } & Number of cases & \% of patients \\
\hline Wasting syndrome & 7089 & 30.7 \\
Esophageal, bronchial, and lung candidiasis & 6782 & 29.4 \\
Pneumocystis carinii pneumonia & 6181 & 26.8 \\
Toxoplasmosis of the brain & 1365 & 5.9 \\
Pulmonary tuberculosis & 874 & 3.8 \\
Kaposi's sarcoma & 997 & 4.3 \\
HIV encephalopathy & 475 & 2.1 \\
\hline
\end{tabular}

Source: Puerto Rico AIDS Surveillance Program.

a Including definitive and presumptive diagnoses, according to criteria of the U.S. Centers for Disease Control and Prevention. Diagnoses were not mutually exclusive, so the same individual could be reported more than once.

\section{CLINICAL SPECTRUM}

The natural history of the disease and the clinical expression of HIV ranges from asymptomatic to mild, moderate, and severe conditions indicative of AIDS. The interval between initial HIV infection and first symptoms and then AIDS varies from individual to individual. Likewise, the clinical expression of disease also varies according to individual characteristics and modes and rates of transmission.

The clinical spectrum of AIDS in Puerto Rico is presented in Table 3. This table used data from the Puerto Rico AIDS Surveillance Program for the period of January 1981 through February 1999 (4). The table includes only the most frequent disease categories, in accordance with the 1993 CDC criteria for AIDS diagnosis (15). The CDC clinical criteria included presumptive and definitive diagnoses for specific opportunistic infection and disease categories. The three main diagnoses in the Puerto Rican population were wasting syndrome; esophageal, bronchial, and lung candidiasis; and Pneumocystis carinii pneumonia (PCP). Toxoplasmosis, pulmonary tuberculosis, and Kaposi's sarcoma were also frequently reported. The clinical categories reported in Table 3 were not mutually exclusive, so that the same individual could be counted more than once. The 1993 CDC criteria for AIDS diagnosis also included the immunological criteria of CD4 cell counts of less than $200 / \mu \mathrm{L}$ and/or CD4 percent- ages of less than $14 \%$; that was true for $44.7 \%$ of the Puerto Rican AIDS population (4).

In the Human Retrovirus Registry of the Universidad Central del Caribe in Bayamón, great emphasis has been placed on the study of the natural history of HIV and AIDS. From May 1992 to December 1997 a total of 1959 HIV/AIDS patients were recruited for a prospective longitudinal study (8). Based on the 1993 CDC definition, at first encounter 960 of the subjects (49\%) had sufficient clinical or immunological criteria to be considered AIDS cases. Among the 960 AIDS cases, 595 of them presented with clinical AIDS and 365 persons were classified as AIDS cases due to low CD4 counts alone. Among the 595 persons with clinical AIDS, the most common infections detected were (by definitive and presumptive CDC criteria): Pneumocystis carinii pneumonia, 229 cases (38.5\%); nonoral candidiasis, $169(28.4 \%)$; toxoplasmosis, 121 (20.3\%); wasting syndrome, 98 (16.5\%); and tuberculosis, 71 (11.9\%). (Different clinical diagnoses could be present in the same individual, so the total number added to more than 595 and the total percent to more than 100\%). The most prevalent non-AIDS opportunistic infections diagnosed among the HIV/AIDS patients were thrush $(28.8 \%)$, bacterial pneumonia $(16.8 \%)$, and skin infections (5.1\%) (8).

An improved quality of life and extended patient survival can come from an early diagnosis of HIV, improved efficacy in the early treatment of the in- 
fection, and prophylactic measures for some opportunistic infections. The time from HIV exposure to onset of disease is highly variable, as is the time from diagnosis of AIDS to death. Some HIV-infected individuals develop rapidly progressive disease, while others remain relatively symptom-free for as long as 10 years after seroconversion. Although numerous studies have examined the influence of transmission mode on disease progression, no definitive evidence has been given for faster or slower progression among members of one risk category or another.

The survival of Puerto Rican patients has been studied. One investigation used the Kaplan-Meier procedure in analyzing median survival time (7). The median survival time after diagnosis was 15.5 months for males (95\% confidence interval: $14.8-16.3 \mathrm{mo})$ and 22.8 months for females (95\% CI: 20.6$25.3 \mathrm{mo}$ ). Another study, with AIDS patients from the San Juan Standard Metropolitan Statistical Area, also showed a shorter survival time for males than for females, 16.4 months (95\% CI: 15.3-17.4 mo) versus 22.7 months (95\% CI: 19.9-26.9 mo) (16).

Another study compared the mortality of wasting syndrome versus Pneumocystis carinii pneumonia in AIDS patients in Puerto Rico (17). Controlling for gender, age, and CD4 levels, the investigation found a higher mortality among the PCP patients.

A study with HIV/AIDS patients in the Bayamón health region of Puerto Rico reported a median survival time of 17.5 months for men and women and suggested that the patients' CD4 cell counts and ages were among the strongest determinants of survival after an AIDS diagnosis. ${ }^{3}$

Studies that describe the effects of newer antiretroviral therapies, with particular emphasis on protease inhibitors, are lacking for HIV-infected patients living in Puerto Rico. It may

\footnotetext{
3 Hunter RF, Miniño A, Gomez MA. Determinations of survival time from AIDS diagnosis to death in a cohort of HIV-infected Puerto Rican patients [conference presentation]. 6th NIH/RCMI International AIDS Symposium, San Juan, Puerto Rico, 1998.
}

be logical to assume, as has been found elsewhere, that patient survival is extended.

\section{SPECIAL GROUPS}

In 1994 the estimated population of Puerto Rico was some 3.6 million, of whom $52.5 \%$ were female and $47.5 \%$ were male (18). The general mortality rate that year was 771 per 100000 inhabitants, with AIDS as the fourthleading cause of death. The AIDS mortality rate had risen from 39.6 per 100000 in 1993 to 42.0 per 100000 in 1994. For the year 1994, the mortality rate for males was higher (67.8 per $100000)$ than for females (17.4 per 100 000). In 1994 AIDS was the first cause of death among persons between 30 and 39 years old and also the most frequent cause of death in males up to 49 years of age. The subsections below describe the toll that the HIV/AIDS epidemic has taken on some special groups.

\section{Women}

The number of HIV-infected women has increased rapidly in the United States and the rest of the world (19, 20). In the United States, the proportion of women among AIDS cases increased from 7\% in 1985 to $18 \%$ in 1994 (19). Between 1991 and 1995 the number of women in the United States diagnosed with AIDS rose by 63\%, a larger percentage increase than for any other group with the disease (21). A similar pattern has been noted in Puerto Rico, where the number of women with AIDS reported to the Puerto Rico AIDS Surveillance Program has been increasing steadily. Between January 1981 and February 1999, a total of 4988 cases of AIDS among women were reported, comprising $21.6 \%$ of the island's reported AIDS cases (4). That is nearly double the proportion of cases that women made up during the five years between 1981 and 1986, 11.4\% (4).

Along with the increase in AIDS cases among women has come a rise in mortality. In the United States in 1994, AIDS was the third-leading cause of death among women between 25 and 44 years old; in 1996, AIDSrelated mortality among women rose by $3 \%$, while falling by $15 \%$ among men (20). In Puerto Rico in 1994, AIDS was the leading cause of death in women between the ages of 25 and 39, and it was the fifth most frequent cause of death among Puerto Rican females, with a mortality rate of 39.6 per 100000 inhabitants (18). Furthermore, this toll is likely to continue rising, given the evidence that women are more at risk of HIV infection than are men when considered either on a percontact or per-partnership basis (1).

The routes of HIV transmission, clinical manifestations, survival time, and impact on reproductive health differ for women and men $(19,20)$. While the impact HIV has on women is multifaceted $(18,22)$, few studies have been done on the natural history of the disease among Hispanic females (21, 22-24). One study of AIDS among Puerto Rican women in the San Juan Standard Metropolitan Statistical Area used data between 1981 through 1995 (16). The male-female ratio found was 3.8:1. The predominant mode of exposure among the women was heterosexual contact $(48.7 \%)$, followed by intravenous drug use (43.3\%). Over that time period an increasing number of women reported heterosexual contact as the mode of exposure to AIDS; between 1993 and 1995, that proportion rose from $45 \%$ to $64 \%$.

Another study analyzed characteristics of 374 Puerto Rican women enrolled in the Human Retrovirus Registry of the Bayamón health region. ${ }^{4}$ The mean age of women in this sample was 35 years; $75 \%$ of them were in their childbearing years, and many were not involved with a regular partner. In addition, a high proportion of them were unemployed and had lim-

\footnotetext{
4 Gomez MA, Fernandez D, Otero JF, Hunter RF HIV/AIDS in Puerto Rican women: spectrum of psychosocial, behavioral and clinical vulnerabilities [conference presentation]. 6th NIH/RCMI International AIDS Symposium, San Juan, Puerto Rico, 1998.
} 
ited education. Almost half of this population reported having had heterosexual relations with an HIVinfected partner, and a similar proportion reported having had heterosexual relations with an injecting drug user. ${ }^{5}$ These results reinforce other research indicating that a large proportion of women with AIDS are IDUs or the sexual partners of IDUs, and also showing that an increasing number of their children are infected (23).

The women in the Bayamón Retrovirus Registry research presented a wide spectrum of psychological vulnerabilities. They sustained frequent episodes of anxiety, confusion, and depression. For all women, living with HIV/AIDS has an immense psychological impact, given the threat of physical deterioration and death, the stress of changes in lifestyles and roles, and the exacerbation of economic and social burdens (25-27). The impact is even more devastating among minority women, who confront restricted social roles, have more limited education levels, and deal with potential cultural barriers related to sexual issues $(24,28)$.

Of the women enrolled in the Bayamón Retrovirus Registry, more than half had arrived at the health care facilities at a late stage of the infection and qualified as AIDS cases. These results were consistent with other research indicating that women seek HIV/AIDS health care later than men do (27). Other studies have described some of the reasons for these delays (28-30). Symptoms may be misinterpreted and the HIV infection not identified. Women involved in care-giving act in detriment to their own health care needs. Some women do not consider HIV a likely diagnosis of their condition.

\section{Children and adolescents}

Pediatric AIDS represents one of the saddest consequences of the epidemic.

\footnotetext{
5 Gomez MA, Fernandez DM, Hunter RF. HIV risk scenario among Puerto Rican HIV/AIDS women [conference presentation]. 6th NIH/RCMI International AIDS Symposium, San Juan, Puerto Rico, 1998.
}

In Puerto Rico 410 pediatric AIDS cases were reported from January 1981 through February 1999. Of these children, $92 \%$ acquired the infection from their mothers, and the rest were infected by contaminated blood or blood products (4).

AIDS is one of the five leading causes of death in Puerto Rico among persons aged 15 years or younger, and it is the second-leading cause of death among those 2-9 years old (20). The majority of these children come from homes where one or both parents have a history of drug use or of risky sexual activities. These families have multiple needs and will often have to rely on external sources of assistance (31).

In most countries around the world the majority of new HIV infections occur in people between the ages of 15 and 24, often resulting from risky sexual behaviors. It has been suggested that adolescents are experiencing sexual relations very early in life and are frequently exposed to unprotected intercourse.

\section{Older persons}

In Puerto Rico an increasing number of HIV infections have been found among older individuals. Data from the Puerto Rico AIDS Surveillance Program indicate that from January 1981 through February 1999, 11\% of the adults registered with AIDS were aged 50 years or older (4). In the United States this older population is usually not perceived as being at risk for HIV infection and is generally left out of targeted prevention programs (32). That is in spite of the fact that an estimated $10 \%$ of the persons in the United States aged 50 or older have at least one risk factor for HIV infection (33). Physicians also tend to underestimate the possibility of HIV infection in this population and may have inadequate knowledge concerning their risk factors (34-35). All this may be contributing to a pattern of late detection of the disease among these older individuals.

In order to better understand this age group in Puerto Rico, a study was carried out to assess the characteristics of a subgroup of $123 \mathrm{HIV}$ patients 55 years and older within a larger cohort study in the Human Retrovirus Registry of the Bayamón health region. ${ }^{6}$ Preliminary results revealed that only 23 of these elderly persons $(18.7 \%)$ were employed. Among the persons in this subgroup $67 \%$ of the females and $52 \%$ of the males reported having heterosexual sex with a risky partner, and $22 \%$ of the males said they had had sex with other males. In addition, $17 \%$ of the females and $43 \%$ of the males had used injectable drugs; fewer than $1 \%$ of them had received a blood product transfusion. Within the preceding year $21 \%$ had been diagnosed or treated for depression and $18 \%$ for anxiety. Other stress events affecting their lives included lost income or other significant economic problems $(20 \%)$ and the death of a person close to them $(17 \%)$.

\section{SOCIAL IMPLICATIONS OF AIDS IN PUERTO RICO}

The economic impact of HIV/AIDS can be enormous for the individual and the family, with such expenses as hospitalization, ambulatory and emergency care, and prescription medicines. The capacity to work is reduced and income is often lost. A recent study of Puerto Rican AIDS patients revealed that most of them were unemployed and that their incomes had fallen significantly (8). The social and psychological impact of AIDS is also enormous, with caregivers, family members, and loved ones having to meet AIDS patients' needs.

Intense efforts are needed to better understand the biology of AIDS and the social, economic, and familial impacts of the epidemic in Puerto Rico. Research leadership in social and behavioral issues is required to translate the understanding of the dynamics

\footnotetext{
6 Gomez MA, Miniño A, Hunter R. HIV/AIDS in a late-middle aged and elderly Puerto Rican population [conference presentation]. National HIV Prevention Conference, Atlanta, Georgia, 1999.
} 
and impact of the epidemic into coherent social and public health action. A key step in that direction would be for medical schools and for university behavioral and social science departments that serve minority students to include a comprehensive curriculum in AIDS-related issues.

Acknowledgments. This research effort was supported by grant G12 RR
03035 from the National Institutes of Health/Research Centers for Minority Institutions and by grant U62/ CCU206209 from the Adult Spectrum of Disease Project of the U.S. Centers for Disease Control and Prevention.

\section{REFERENCES}

1. Mann J, Tarantola D, Netter TW, eds. A global epidemic out of control? In: AIDS in the world, a global report. Cambridge, Massachusetts: Harvard University Press; 1992. p. 1-82.

2. United Nations Programme on HIV/AIDS. Report on the global HIV/AIDS epidemic December 1997 [Internet site]. Available from: http://www.us.unaids.org. Accessed 25 January 1999.

3. United Nations Programme on HIV/AIDS. AIDS epidemic update 1998 [Internet site]. Available from: http://www.us.unaids.org. Accessed 25 January 1999.

4. Commonwealth of Puerto Rico, Puerto Rico AIDS Surveillance Program. Puerto Rico AIDS surveillance report. San Juan, Puerto Rico: Commonwealth of Puerto Rico, Puerto Rico AIDS Surveillance Program; 1999.

5. United States, Centers for Disease Control and Prevention. HIV/AIDS Surveillance Report;10(1):June 1998.

6. Commonwealth of Puerto Rico, Puerto Rico AIDS Surveillance Program. Puerto Rico AIDS surveillance report by health region. San Juan, Puerto Rico: Commonwealth of Puerto Rico, Puerto Rico AIDS Surveillance Program; 1999.

7. Perez-Perdomo R, Suarez E, Perez-Cardona C, Morales A. Epidemiologic profile of HIV/ AIDS in Puerto Rico: 1981-1996. Mexico, D.F.: University of Puerto Rico and Glaxo Wellcome; 1998

8. Gomez MA, Velazquez M, Hunter RF. Outline of the Human Retrovirus Registry: profile of a Puerto Rican HIV infected population. Boletín Asociación Médica de Puerto Rico 1997;89:7-9, 111-116.

9. Menendez B, Drucker E, Vermund S, Castano RR, Perez-Agosto RR, Parga FJ, et al. AIDS mortality among Puerto Rican and other Hispanics in New York City, 1981-1987. J Acquir Immune Defic Syndr 1990;3(6): 644-648.

10. Robles RR, Cancel LI, Colon HM, Matos TD, Freeman DH, Sahai H. Prospective effects of perceived risk of developing HIV/AIDS on risk behaviors among injection drug users in Puerto Rico. Addiction 1995;90(8):1105-1111.

11. Selik RM, Castro KG, Pappaioanou M, Buehler JW. Birthplace and the risk of AIDS among Hispanics in the United States. Am J Public Health 1989;79(7):836-839.

12. Robles RR, Colon HM, Sahai H, Matos TD, Marrero CA, Reyes JC. Behavioral risk factors Press; 1994. p. 55-70. and human immunodeficiency virus (HIV) prevalence among intravenous drug users in Puerto Rico. Am J Epidemiol 1992;135(5): 531-540

13. Velez CN, Rodriguez LA, Quiñones HM, Schoenbaum E. HIV risk factors among Puerto Rican youth in drug treatment. P R Health Sci J 1993;12(3):203-209.

14. Gomez MA, Fernandez DM, Hunter RF. Psychosocial and clinical spectrum of HIV/AIDS injecting drug users in Bayamón, Puerto Rico. Cell Mol Biol (Noisy-le-grand) 1997;43(7): 1145-1152.

15. Centers for Disease Control. 1993 revised classification system for HIV infection and expanded surveillance case definition for AIDS among adolescent and adults. CDC prevention guidelines. MMWR, 41(RR 17);1992.

16. Perez-Perdomo R, Suarez-Perez EL, PerezCardona CM. Epidemiologic profile of AIDS among Puerto Rican women in the San Juan Standard Metropolitan Statistical Area, 19811995. Cell Mol Biol (Noisy-le-grand) 1997; 43(7):1131-1138.

17. Mayor-Becerra AM, Suarez EL, Morales A. Pneumocystis carinii pneumonia versus wasting syndrome among AIDS cases in Puerto Rico: a survival analysis. P R Health Sci J 1996;15(4):257-260.

18. Commonwealth of Puerto Rico, Health Department, Statistics Branch. Vital statistics report, 1994. San Juan: Health Department; 1999.

19. Chu SY, Wortley PM. Epidemiology of HIV/ AIDS in women. In: Minkoff $\mathrm{H}$, DaHovitz JA, Duerr A, eds. HIV infection in women. New York: Raven Press; 1994. p. 1-12.

20. United States, Centers for Disease Control and Prevention. Facts about women and HIV [Internet site]. Available from: http//www. cdcnpin.org. Accessed 21 January 1999.

21. Wortley PM, Fleming PL. AIDS in women in the United States: recent trends. JAMA, 1997;278(11):911-916.

22. Zorrilla C, Diaz C, Romaguera, J, Martin M. Acquired immune deficiency syndrome (AIDS) in women and children in Puerto Rico. In: Lamberty G, Garcia-Coll C, eds. Puerto Rican women and children: issues in health, growth and development. New York: Plenum

23. Kilbourne BW, Gwinn M, Castro KG, Oxtoby MJ. HIV infection and AIDS among women: impact on Hispanics. In: Lamberty G, GarciaColl C, eds. Puerto Rican women and children: issues in health, growth and development. New York: Plenum Press; 1994. p. 103-117.

24. Worth D, Rodriguez R. Latina women and AIDS. Radical America 1987;20:63-67.

25. Abercrombie PD. Women living with HIV infection. Nurs Clin North Am 1996;31(1): 97-106.

26. Pergami A, Burgess A, Durbano F, Zanello D, Riccio M, Invernizzi $G$, et al. The psychosocial impact of HIV infection in women. J Psychosom Res 1993;37(7):687-696.

27. Sher R. The role of women in the AIDS epidemic. Med Law 1993;12(6-8):467-469.

28. Nyamathi A, Shuler P, Proche M. AIDS educational program for minority women at risk. Fam Community Health 1990;13:54-64.

29. Sherr L. Psychosocial aspects of providing care for women with HIV infection. In Minkoff HL, DeHovitz A, Duerr A, eds. HIV infection in women. New York: Raven Press; 1995. p. 107-123.

30. Hankins CA. Women and HIV infection and AIDS in Canada. Should we worry? CMAJ 1990;143(11):1171-1173.

31. Geballe S, Gruendel J, Andiman W. Forgotten children of the AIDS epidemic. New Haven, Connecticut: Yale University Press; 1995.

32. el-Sadr W, Gettler J. Unrecognized human immunodeficiency virus infection in the elderly. Arch Intern Med 1995;155:184-186.

33. Stall R, Catania J. AIDS risk behaviors among late middle-aged and elderly Americans. The National AIDS Behavioral Surveys. Arch Intern Med 1994;154(1):57-63.

34. Schuerman DA, Clinical concerns: AIDS in the elderly. J Gerontol Nurs 1994;20(7):11-17.

35. Skiest DJ, Keiser P. Human immunodeficiency virus infection in patients older than 50 years. A survey of primary care physician's beliefs, practices, and knowledge. Arch Fam Med 1997;6(3):289-294.

Manuscript received on 13 October 1999. Revised version accepted for publication on 8 February 2000. 
RESUMEN Este estudio presenta información sobre los pacientes con sida en Puerto Rico, como su perfil sociodemográfico general, los factores de riesgo, las características de los grupos vulnerables y los elementos del espectro clínico de la enfermedad. Los datos analizados procedían del Programa de Vigilancia del sida en Puerto Rico y de estudios sobre la epidemia de VIH/sida en la isla. De enero de 1981 a febrero de 1999 se habían comunicado a dicho programa 23089 casos de sida. La epidemia de VIH/ sida ha afectado sobre todo a varones y hembras de 30 a 49 años, aunque también se han descrito casos en otros grupos de edad. La proporción acumulada de pacientes del sexo femenino con sida ha aumentado enormemente, de $11,4 \%$ en el período 1981-1986 a 21,6\% en el período 1981-1999. En Puerto Rico, el grupo de adictos a drogas por vía parenteral representa la mayoría de los casos de sida $(52 \%)$, seguido de los heterosexuales $(22 \%)$ y de los varones homosexuales $(17 \%)$. Los tres diagnósticos de sida establecidos con mayor frecuencia en la isla son el síndrome consuntivo $(30,7 \%)$, la candidiasis esofágica, bronquial y pulmonar $(29,4 \%)$ y la neumonía por Pneumocystis carinii $(26,8 \%)$. De acuerdo con las estadísticas demográficas de 1994 en Puerto Rico, el sida constituyó la cuarta causa de muerte. La tasa global de mortalidad por sida fue de 42,0 por 100000 habitantes, siendo mucho más elevada en los hombres $(67,8)$ que en las mujeres $(17,4)$. El sida es la primera causa de muerte en personas de 30 a 39 años de edad. Serán necesarios grandes esfuerzos para comprender mejor la epidemia en Puerto Rico, su biología, su impacto social y familiar y sus costes financieros. 